\title{
IMPLEMENTASI MODEL PERANGKAT PEMBELAJARAN BERORIENTASI HOTS (HIGH ORDER THINKING SKILLS) DAN PENDIDIKAN KARAKTER MELALUI PBL (PROBLEM BASED LEARNING) PADA MATA KULIAH FISIKA DASAR
}

\author{
Indra Saktia) \\ Program Studi Pendidikan IPA-Fisika FKIP Universita Bengkulu, Jalan Raya Kandang Limun Bengkulu \\ Email: a) isakti@unib.ac.id
}

\begin{abstract}
Abstrak
Dilakukan penelitian action reseach untuk mengimplementasi perangkat Pembelajaran Berbasis HOTS (Higher Order Thinking Skill) dan Pendidikan Karakter melalui model Problem Based Learning (PBL) di Program Studi Pendidikan IPA Jurusan Pendidikan MIPA Fakultas Keguruan dan Ilmu Pendidikan Universitas Bengkulu tahun 2018 untuk mata kuliah Fisika Dasar. Adapun tujuan penelitian adalah (1) Mendeskripsikan aktivitas belajar mahasiswa dalam proses pembelajaran model PBL berbasis HOTS dan pendidikan karakter pada Matakuliah Fisika Dasar. (2) Mendeskripsikan kemampuan berpikir tingkat tinggi (HOTS) mahasiswa setelah pembelajaran PBL berbasis HOTS dan pendidikan karakter. (3) Mendeskripsikan karakter mahasiswa setelah pembelajaran PBL berbasis HOTS dan pendidikan karakter. Kegiatan penelitian ini dilakukan tiga siklus dengan 4 kali pertemuan. Setiap siklus terdiri dari empat langkah penelitian yaitu perencanaan, pelaksanaan, observasi, dan refleksi. Perangkat pembelajaran terdiri dari (1) RPP dengan model problem based learning (PBL) berbasis HOTS dan Pendidikan Karakter; (2) bahan ajar materi Suhu dan Kalor berorientasi HOTS dan Pendidikan Karakter; (3) LKPD; (4) instrumen penilaian (a) Keterampilan berpikir tingkat tinggi dan (b) karakter. Instrumen penelitian terdiri dari lembar observasi, catatan lapangan, angket, rubrik penilaian proses pembelajaran, soal pretest dan posttest untuk pengukuran kemampuan berpikir tingkat tinggi, dan penilaian karakter. Indikator penilaian keterampilan berpikir tingkat tinggi : (H1), keterampilan berpikir kritis (critical thinking), (H2), berpikir kreatif (creative thinking), (H3), kemampuan berargumen (reasoning), dan (H4), kemampuan mengambil keputusan (decision making). Indikator karakter adalah (K1) jujur, (K2) disiplin, (K3) ingin tahu, (K4) tanggung jawab. Teknik analisis data menggunakan analisis deskriptif. Hasil penelitian yang diperoleh adalah (1) adanya peningkatan aktivitas belajar mahasiswa dalam proses pembelajaran PBL berbasis HOTS dan pendidikan karakter pada Matakuliah Fisika Dasar. (2) adanya peningkatan kemampuan berpikir tingkat tinggi (HOTS) mahasiswa setelah pembelajaran PBL berbasis HOTS dan pendidikan karakter. (3) adanya peningkatan karakter mahasiswa setelah pembelajaran PBL berbasis HOTS dan pendidikan karakter.
\end{abstract}

Kata-kata kunci: action research, model perangkat pembelajaran, HOTS, Karakter, problem based Learning. 


\section{PENDAHULUAN}

Mahasiswa sebagai anggota masyarakat abat 21, saat ini menghadapi berbagai tantangan, baik tantangan di tingkat lokal, nasional, regional, maupun internasional. di antaranya adalah memiliki kemampuan yang sering disingkat 4C, yaitu communication, collaboration, ctritical thinking and problem solving, dan creativity and innovation. Demikian juga halnya tantangan yang dihadapi guru abad 21. Ada tujuh tantangan yang dihadapi guru abad 21 yaitu: (1) mengajar di masyarakat yang memiliki beragam budaya dengan kompetensi multi bahasa; (2) mengajar untuk mengkronstruksi makna; (3) mengajar untuk pembelajaran aktif; (4) mengajar dan teknologi; (5) mengajar dengan pandangan baru mengenai kemampuan; (6) mengajar dan pilihan; dan (7) mengajar dan akuntabilitas. Selanjutnya tantangan yang dihadapi guru meliputi : (1) pendidikan berfokus pada characterr building; (2) pendidikan yang peduli pada perubahah iklim; (3) enterprenual mindset; (4) membangun learning community; dan kekuatan bersaing bukan lagi kepandaian tetapi kreativitas dan kecerdasan bertindak. [1]

Depdikbud menjelaskan bahwa secara garis besar, terdapat 3 kelompok kompetensi yang dibutuhkan pada abad ke-21 (21st century skills) yaitu: a) memiliki karakter yang baik (beriman dan taqwa, rasa ingin tahu, pantang menyerah, kepekaan sosial dan berbudaya, mampu beradaptasi, serta memiliki daya saing yang tinggi); b) memiliki sejumlah kompetensi (berpikir kritis dan kreatif, problem solving, kolaborasi, dan komunikasi); serta c) menguasai literasi mencakup keterampilan berpikir menggunakan sumber-sumber pengetahuan dalam bentuk cetak, visual, digital, dan auditori.[1]

Demikian juga halnya sebagai mahasiswa PS Pendidikan IPA sebagai calon guru IPA, HOTS sangat penting untuk dapat menjalani hidup dan kehidupan, karena HOTS merupakan keterampilan penting untuk keberhasilan studi, bekerja, dan hidup di era informasi dan teknologi abad ke-21. HOTS dan komponennya ini dapat dikembangkan dan digunakan dengan baik ketika mempelajari suatu pengetahuan dan menyelesaikan serta mensikapi sebuah permasalahan. Dosen dapat mendorong mahasiswa untuk menggunakan HOTS tersebut dalam setiap kegiatan pembelajaran, baik dalam diskusi, kegiatan lapangan, praktikum, maupun kegiatan pembelajaran lainnya, dan mahasiswa diberi kesempatan untuk mengevaluasi sendiri kemampuannya.

Pengembangan HOTS bagi mahasiswa sangat penting untuk mengembangkan secara komprehensif kemampuan dan keterampilan mahasiswa dalam hal berpikir kritis, sistematis, logis, aplikatif, analitis, evaluatif, kreatif, pemecahan masalah, dan pengambilan keputusan secara jujur, percaya diri, bertanggung jawab dan mandiri. Dengan kemampuan ini, mahasiswa dapat menentukan sikap dan perilaku yang baik, dan apabila perilaku baik ini senantiasa dilakukan secara konsisten maka akan terbentuk karakter yang baik pada diri mahasiswa. Selain itu, mahasiswa juga akan mampu berkompetisi dalam dunia global dan pergaulan internasional. Di sinilah peran HOTS dalam pembentukan karakter yang baik (good character) bagi mahasiswa. Dengan demikian, apabila HOTS ini dikembangkan melalui model problem based learning berbasis HOTS pada mahasiswa, maka diharapkan mahasiswa memperoleh pembinaan dalam keterampilan berpikir tingkat tinggi maupun dalam penguasaan materi subjek dan pembentukan good character yang akan berguna bagi pengembangan karirnya kelak.

Berdasarkan uraian di atas, dipandang perlu melakukan penelitian tentang pembelajaran fisika yang berbasis HOTS dan pendidikan karakter. Penelitian ini berusaha memberikan kontribusi dalam pembelajaran fisika berbasis HOTS dan pembentukan good character bagi mahasiswa melalui penerapan problem based learning. Hal ini didukung oleh hasil penelitian Barak \& Dori (2009) yang meneliti tentang bagaimana meningkatkan HOTS mahasiswa calon guru sains melalui penilaian yang ditanamkan (embedded assessment) dalam pembelajaran. Hasil penelitian Barak \& Dori tersebut menemukan bahwa dengan menerapkan sebuah penilaian yang terintegrasi dalam pembelajaran, maka dapat meningkatkan HOTS mahasiswa.

Berdasarkan latar belakang sebagaimana diuraikan diatas maka rumusan masalah penelitian ini adalah (1) Bagaimana aktivitas belajar mahasiswa dengan penerapan model perangkat pembelajaran berorientasi HOTS dan pendidikan karakter melalui pembelajaran berbasis masalah (problem based learning)? (2) Bagaimana keterampilan berpikir tingkat tinggi (Higher Order Thinking Skills) 
mahasiswa dengan penerapan model perangkat pembelajaran berorientasi HOTS dan pendidikan karakter melalui pembelajaran berbasis masalah (problem based learning)? (3) Bagaimana karakter mahasiswa setelah penerapan model perangkat pembelajaran berorientasi HOTS dan pendidikan karakter melalui pembelajaran berbasis masalah (problem based learning) ? Berdasarkan masalah penelitian maka yang menjadi tujuan yang akan dicapai melalui penelitian ini adalah (1) Mendeskripsikan aktivitas belajar mahasiswa dengan penerapan model perangkat pembelajaran berorientasi HOTS dan pendidikan karakter melalui pembelajaran berbasis masalah (problem based learning). (2 ) Mendeskripsikan keterampilan berpikir tingkat tinggi (HOTS) mahasiswa setelah penerapan model perangkat pembelajaran berorientasi HOTS dan pendidikan karakter melalui pembelajaran berbasis masalah (problem based learning). (3) Mendeskripsikan karakter mahasiswa setelah penerapan model perangkat pembelajaran berorientasi HOTS dan pendidikan karakter melalui pembelajaran berbasis masalah (problem based learning).

\section{KAJIAN PUSTAKA}

\section{Keterampilan Berpikir Tingkat Tinggi (Higher Order Thinking Skill/HOTS)}

Kemampuan berpikir tingkat tinggi adalah kemampuan menghubungkan, memanipulasi dan mentransformasi pengetahuan serta pengalaman yang sudah dimiliki untuk berpikir kritis dan kreatif dalam upaya menentukan keputusan dan memecahkan masalah pada situasi baru [2]. Kemampuan berpikir tingkat tinggi termasuk kemampuan untuk memecahkan masalah (problem solving), keterampilan berpikir kritis (critical thinking), berpikir kreatif (creative thinking), kemampuan berargumen (reasoning), dan kemampuan mengambil keputusan (decision making) [1].

High Order Thinking Skills merupakan suatu proses berpikir dalam level kognitif yang lebih tinggi yang dikembangkan dari berbagai konsep dan metode kognitif dan taksonomi pembelajaran seperti metode problem solving, taksonomi bloom, dan taksonomi pembelajaran, pengajaran, dan penilaian [3]. High order thinking skills ini meliputi di dalamnya kemampuan pemecahan masalah, kemampuan berpikir kreatif, berpikir kritis, kemampuan berargumen, dan kemampuan mengambil keputusan. Menurut King, high order thinking skills termasuk di dalamnya berpikir kritis, logis, reflektif, metakognitif, dan kreatif, sedangkan menurut Newman dan Wehlage dengan high order thinking peserta didik akan dapat membedakan ide atau gagasan secara jelas, berargumen dengan baik, mampu memecahkan masalah, mampu mengkonstruksi penjelasan, mampu berhipotesis dan memahami hal-hal kompleks menjadi lebih jelas [2].

Dalam Taksonomi Bloom revisi Anderson \& Krathworl kemampuan yang melibatkan aspek menganalisis (C4), mengevaluasi (C5), dan mencipta atau kreativitas (C6) dianggap berpikir tingkat tinggi [4]. Anderson menjelaskan proses berpikir dan menjabarkan berpikir tingkat rendah ke berpikir tingkat tinggi dapat dilihat pada TABEL 2.2 berikut:

TABEL 2.2 Dimensi Proses Berpikir

\begin{tabular}{|c|l|l|}
\hline \multirow{3}{*}{ HOTS } & Mengkreasi & Mengkreasi ide/gagasan sendiri. \\
\cline { 2 - 3 } & Mengevaluasi & Mengambil keputusan sendiri. \\
\cline { 2 - 3 } & Menganalisis & Mengspesifikasi aspek-aspek/elemen. \\
\hline \multirow{3}{*}{ MOTS } & Mengaplikasika & $\begin{array}{c}\text { Menggunakan informasi pada domain yang } \\
\text { berbeda. }\end{array}$ \\
\cline { 2 - 3 } & Memahami & Menjelaskan ide/konsep. \\
\hline LOTS & Mengetahui & Mengingat kembali. \\
\hline
\end{tabular}

(Sumber: Anderson \& Krathwohl dalam (Kemendikbud, 2017))

Perspektif dua dimensi domain kognitif, yaitu knowledge dimension (dimensi pengetahuan) dan cognitive process dimension (dimensi proses kognisi), untuk kemampuan berpikir tingkat tinggi dan klasifikasi kata kerja operasionalnya dapat dilihat pada TABEL 2.3 berikut ini [4]:

TABEL 2.3 Dimensi Domain Kognitif dan Kata Kerja Operasional untuk Kemampuan Berpikir Tingkat Tinggi 


\begin{tabular}{|c|l|l|l|}
\hline \multirow{2}{*}{$\begin{array}{c}\text { Dimensi } \\
\text { Pengetahuan }\end{array}$} & \multicolumn{2}{|c|}{ Dimensi Proses Kognitif } \\
\cline { 2 - 4 } & $\begin{array}{l}\text { C4 } \\
\text { (Menganalisis) }\end{array}$ & $\begin{array}{c}\text { C5 } \\
\text { (Mengevaluasi) }\end{array}$ & $\begin{array}{l}\text { C6 } \\
\text { (Mencipta) }\end{array}$ \\
\hline $\begin{array}{c}\text { Pengetahuan } \\
\text { Faktual (PF) }\end{array}$ & $\begin{array}{l}\text { Memutuskan, } \\
\text { Mengklasifikasikan }\end{array}$ & $\begin{array}{c}\text { Memeriksa, } \\
\text { Mengkritik }\end{array}$ & $\begin{array}{l}\text { Menghasilkan } \\
\text { Menggabungkan }\end{array}$ \\
\hline $\begin{array}{c}\text { Pengetahuan } \\
\text { Konseptual (PK) }\end{array}$ & $\begin{array}{l}\text { Membedakan, } \\
\text { Menguraikan } \\
\text { Menjelaskan }\end{array}$ & $\begin{array}{c}\text { Menetapkan, } \\
\text { Meninjau }\end{array}$ & $\begin{array}{l}\text { Mengumpulkan, } \\
\text { Merencanakan }\end{array}$ \\
\hline $\begin{array}{c}\text { Pengetahuan } \\
\text { Prosedural (PP) }\end{array}$ & $\begin{array}{l}\text { Mengintegrasikan, } \\
\text { Membandingkan }\end{array}$ & $\begin{array}{l}\text { Mengevaluasi, } \\
\text { Menyimpulkan }\end{array}$ & $\begin{array}{c}\text { Mendesain, } \\
\text { Mengembangkan, } \\
\text { Menggubah }\end{array}$ \\
\hline $\begin{array}{c}\text { Pengetahuan } \\
\text { Metakognitif (PM) }\end{array}$ & $\begin{array}{c}\text { Memperoleh, } \\
\text { Menganalisis }\end{array}$ & $\begin{array}{l}\text { Merefleksikan, } \\
\text { Memprioritaskan, } \\
\text { Menilai }\end{array}$ & $\begin{array}{l}\text { Memproduksi, } \\
\text { Membuat, } \\
\text { Mengaktualisasikan }\end{array}$ \\
\hline
\end{tabular}

Dijelaskan bahwa dimensi pengetahuan terdiri atas; fakta, konsep, prosedur, dan metakognisi, yaitu 1) pengetahuan faktual meliputi elemen-elemen dasar yang harus diketahui siswa jika akan mempelajari suatu disiplin ilmu atau menyelesaikan masalah, 2) pengetahuan konseptual mencakup pengetahuan tentang kategori, klasifikasi, dan hubungan antara dua atau lebih kategori, 3) pengetahuan prosedural adalah pengetahuan tentang cara melakukan sesuatu seperti mengerjakan latihan rutin sampai menyelesaikan masalah-masalah yang baru dan meliputi pengetahuan tentang keterampilan, algoritme, teknik, metode, dan kriteria, dan 4) pengetahuan metakognitif yang meliputi pengetahuan tentang strategi, pengetahuan tentang tugas-tugas kognitif (pengetahuan kontekstual dan kondisional), dan pengetahuan diri.

\section{Karakter}

Menurut Pusat Bahasa Depdiknas karakter adalah bawaan, hati, jiwa, kepribadian, budi pekerti, perilaku, personalitas, sifat, tabiat, temperamen, watak". Sehingga, orang yang berkarakter adalah orang yang berkepribadian, berperilaku, bersifat, bertabiat, berwatak". Karakter sebagai cara berpikir dan berperilaku yang menjadi ciri khas tiap individu untuk hidup dan bekerja sama dalam lingkup keluarga, masyarakat, bangsa dan negara. Individu yang berkarakter baik adalah individu yang bisa membuat keputusan dan siap mempertanggungjawabkan setiap akibat dari keputusan yang dibuatnya [5].

Berdasarkan definisi karakter yang telah dikemukakan di atas, dapat disimpulkan bahwa di dalam karakter terkandung tiga kata kunci yaitu cara berpikir, bersikap, dan bertindak atau berperilaku. Berikut disajikan pengertian karakter sbb (1)jujur, yakni perilaku yang didasarkan pada upaya menjadikan dirinya sebagai orang yang selalu dapat dipercaya dalam perkataan, tindakan, dan pekerjaan, (2) disiplin yakni tindakan yang menunjukkan perilaku tertib dan patuh pada berbagai ketentuan dan peraturan, (3) kreatif yakni berpikir dan melakukan sesuatu untuk menghasilkan cara atau hasil baru dari sesuatu yang telah dimiliki, (4) tanggung jawab yakni sikap dan perilaku seseorang untuk melaksanakan tugas dan kewajibannya, yang seharusnya dia lakukan, terhadap diri sendiri, masyarakat, lingkungan (alam, sosial dan budaya), negara dan Tuhan Yang Maha Esa.

\section{Model Problem Based Learning}

Problem Based Learning (Pembelajaran Berbasis Masalah) adalah pembelajaran yang menggunakan masalah nyata sehari-hari (otentik) yang bersifat terbuka (open-ended) untuk diselesaikan oleh peserta didik dalam rangka mengembangkan keterampilan berpikir, keterampilan menyelesaikan masalah, keterampilan sosial, keterampilan untuk belajar mandiri, dan membangun atau memperoleh pengetahuan baru. Pemilihan masalah nyata tersebut dilakukan atas pertimbangan kesesuaiannya dengan pencapaian kompetensi dasar.

Problem-based learning (PBL) merupakan salah satu pendekatan pembelajaran yang menghadapkan mahasiswa pada permasalahan dalam kehidupan nyata. The essence of problem-based learning consists of presenting student with authentic and meaningful problem situations that can serve as springboards for investigation and inquiri. Bahwa esensi dari problem based learning adalah 
menghadapkan mahasiswa pada masalah yang autentik dan bermakna bagi mahasiswa serta mendorong mahasiswa melakukan kegiatan investigasi dan penemuan [6].

Problem-based learning is an instructional strategy that encourages student to develop critical thinking and problemsolving skills that they can carry with them throughout their lifetimes. Artinya bahwa problem-based learning merupakan strategi pembelajaran yang mendukung mahasiswa untuk mengembangkan berpikir kritis dan keterampilan pemecahan masalah sehingga mereka dapat membawa atau menggunakan keterampilan tersebut sepanjang hidup mereka. Seperti halnya yang diungkapkan "Problem Based Learning (PBL) is an instructional strategy that encourages students to develop critical thinking and problem-solving skills that they can carry with them throughout their lifetimes". Maksudnya bahwa pembelajaran berbasis masalah merupakan suatu strategi pembelajaran yang mendorong mahasiswa untuk mengembangkan kemampuan berpikir kritis dan dapat menyelesaikan masalah yang dapat digunakan mereka sepanjang hidupnya [6].

TABEL 2.4. Langkah-Langkah Pembelajaran Berbasis Masalah

\begin{tabular}{|c|c|}
\hline Tahap & Deskripsi \\
\hline $\begin{array}{l}\text { Tahap } 1 \\
\text { Orientasi terhadap } \\
\text { masalah }\end{array}$ & Menyajikan masalah nyata kepada mahasiswa. \\
\hline $\begin{array}{l}\text { Tahap } 2 \\
\text { Organisasi belajar }\end{array}$ & $\begin{array}{l}\text { memfasilitasi mahasiswa untuk memahami masalah nyata yang telah } \\
\text { disajikan, yaitu mengidentifikasi apa yang mereka ketahui, dan apa } \\
\text { yang perlu dilakukan untuk menyelesaikan masalah. Mahasiswa berbagi } \\
\text { peran/tugas untuk menyelesaikan masalah tersebut. }\end{array}$ \\
\hline $\begin{array}{l}\text { Tahap } 3 \\
\text { Penyelidikan } \\
\text { individual maupun } \\
\text { kelompok }\end{array}$ & $\begin{array}{l}\text { membimbing mahasiswa melakukan pengumpulan data/ informasi } \\
\text { (pengetahuan, konsep, teori) melalui berbagai macam cara untuk } \\
\text { menemukan berbagai alternatif penyelesaian masalah. }\end{array}$ \\
\hline $\begin{array}{l}\text { Tahap } 4 \\
\text { Pengembangan dan } \\
\text { penyajian hasil } \\
\text { penyelesaian } \\
\text { masalah }\end{array}$ & $\begin{array}{l}\text { membimbing mahasiswa untuk menentukan penyelesaian masalah } \\
\text { yang paling tepat dari berbagai alternatif pemecahan masalah yang } \\
\text { mahasiswa temukan. Mahasiswa menyusun laporan hasil penyelesaian } \\
\text { masalah, misalnya dalam bentuk gagasan, model, bagan, atau Power } \\
\text { Point slides. }\end{array}$ \\
\hline $\begin{array}{l}\text { Tahap 5 } \\
\text { Analisis dan } \\
\text { evaluasi proses } \\
\text { penyelesaian masalah }\end{array}$ & $\begin{array}{l}\text { memfasilitasi mahasiswa untuk melakukan refleksi atau evaluasi } \\
\text { terhadap proses penyelesaian masalah yang dilakukan. }\end{array}$ \\
\hline
\end{tabular}

\section{A. Kerangka Berpikir}

Implementasi pembelajaran model problem based learning berbasis HOTS dan pendidikan karakter diharapkan mampu meningkatkan kualitas mahasiswa calon guru IPA. Kerangka pemikiran penelitian ini diGAMBARkan sebagai berikut; 


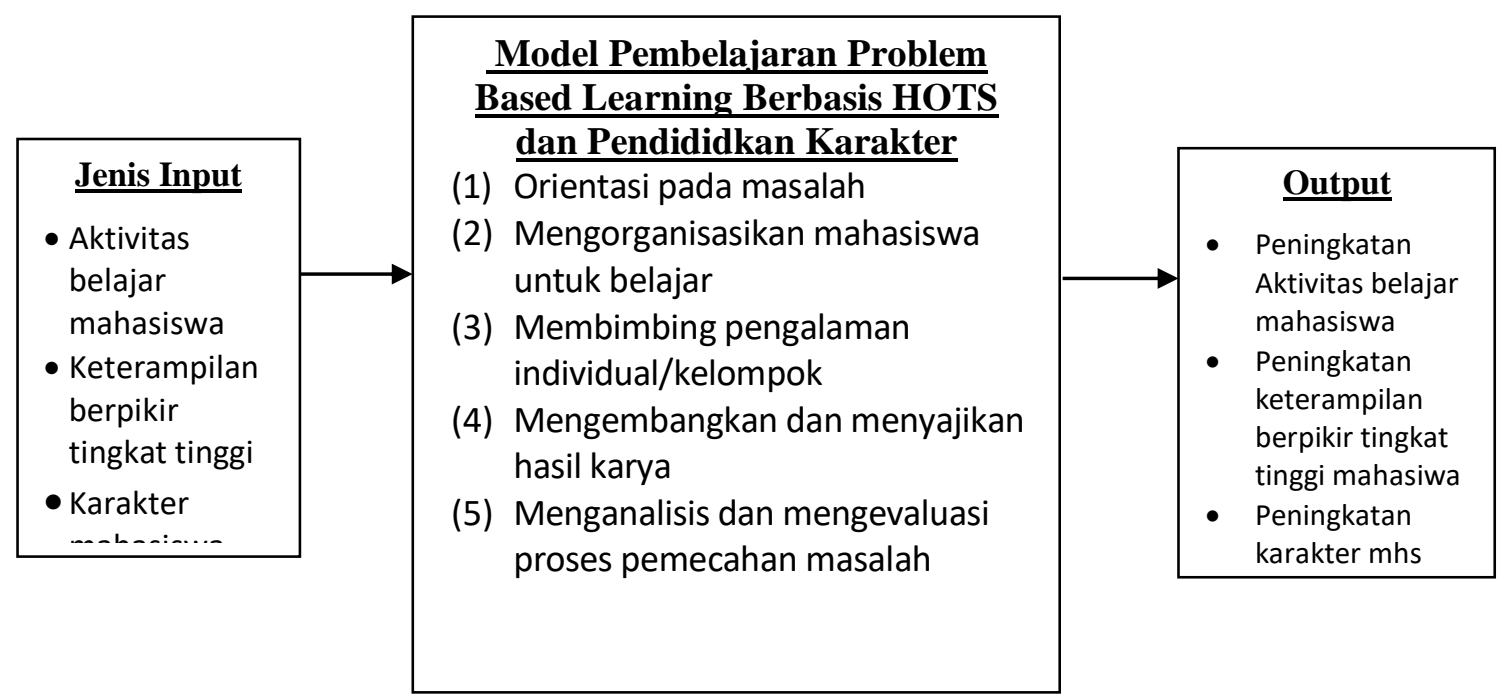

Untuk itu perangkat pembelajaran fisika dasar yang dikembangkan terdiri dari RPP bahan ajar, LK dan perangkat evaluasinya.

\section{METODOLOGI}

Penelitian ini merupakan penelitian Penelitian Tindakan Kelas (Classroom Action Research). meliputi beberapa tahapan yaitu perencanaan, tindakan, pengamatan, refleksi. Tempat penelitian ini dilakukan di PS Pendidikan IPA FKIP Unib kelas mata kuliah fisika dasar pada semester genap tahun ajaran 2018/2019. Subjek penelitian adalah seluruh mahasiswa semester I. Variabel penelitian ini adalah sebagai berikut: 1) HOTS (Kemampuan berpikir Tingkat Tinggi), 2) Karakter. HOTS mahasiswa diukur dengan menggunakan instrumen tes, dan aktivitas belajar mahasiswa diukur dengan menggunakan intrumen pengamatan serta karakter mahasiswa dilakukan dengan asesmen diri (self assessement). Adapun karakter diteliti adalah jujur, disiplin, ingin tahu, tanggung jawab. Instrumen penelitian ini berupa lembar orservasi, angket dan tes hasil belajar. Instrumen penelitian sebelum digunakan dilakukan uji validasi. Validitasi Instrumen dilakukan dengan (a) validasi isi (content validity), dimana untuk validitas ahli dilakukan oleh dosen. Analisis data dilakukan dengan uji deskriptif.

\section{HASIL DAN PEMBAHASAN}

\section{A. Deskripsi Subjek Penelitian}

Subjek penelitian sebanyak 26 mahasiswa Program Studi Pendidikan IPA FKIP Universitas Bengkulu. Implementasi pembelajaran 3 siklus dengan masing-masing siklus empat langkah yaitu perencanaan, tindakan, observasi dan refleksi. Setiap pelaksanaan pembelajaran diterapkan model pembelajaran berbasis masalah (problem based learning) dengan membentuk kelompok belajar, yang. masing-masing kelompok terdiri dari 5 orang.

\section{B. Hasil Penelitian dan Pembahasan}

\section{a. Data Hasil Pengamatan Aktivitas Mahasiwa}

TABEL 4.2 Data Aktivitas Belajar Mahasiswa

\begin{tabular}{lllll} 
No Langkah PBL & Siklus & Siklus & Siklus \\
& I & II & III \\
\hline
\end{tabular}


I. Pendahuluan

\begin{tabular}{lllll}
\hline & Apersepsi dan motivasi & 3 & 3 & 4 \\
\hline II. & Kegiatan Inti PBL: & & & \\
\hline 1 & Fase 1 Orientasi peserta didik kepada masalah & 3 & 3 & 4 \\
\hline 2 & Fase 2 Mengorganisasikan peserta didik & 3 & 4 & 4 \\
\hline 3 & Fase 3 Membimbing penyelidikan individu/ kelompok & 2 & 3 & 4 \\
\hline 4 & Fase 4 Mengembangkan dan menyajikan hasil karya & 2 & 3 & 4 \\
\hline 5 & $\begin{array}{l}\text { Fase 5 Menganalisa dan mengevaluasi proses } \\
\text { pemecahan masalah }\end{array}$ & 2 & 3 & 3 \\
\hline
\end{tabular}

\section{Penutup}

\begin{tabular}{llll}
\hline Evaluasi & 3 & 3 & 4 \\
\hline Pengayaan dan Remedial & 3 & 3 & 3 \\
\hline Jumlah & 21 & 24 & 30 \\
\hline Rata-rata & 2,625 & 3 & 3,75 \\
\hline Kategori & Cukup & Baik & SB \\
\hline
\end{tabular}

Aktifitas mahasiswa merupakan respon mahasiswa terhadap pembelajaran yang diberikan dengan aspek penilaian yang telah ditentukan sebelumnya. Berikut adalah GAMBARan kenaikan rata-rata aktifitas belajar mahasiswa pada setiap siklus yang ditunjukkan pada grafik dibawah ini.

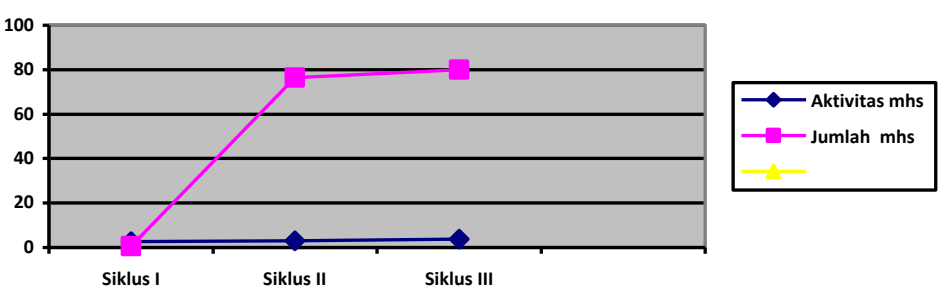

Grafik Kenaikan Aktivitas Mahasiswa pada setiap siklus

Aktifitas mahasiswa setiap siklusnya mengalami peningkatan. Untuk siklus I sebanyak 65,48 \% mahasiswa dapat dikatakan melakukan aktifitas pembelajaran, kemudian pada siklus II meningkat menjadi 76,40 \% siswa. Kemudian aktifitas mahasiswa pada siklus III menjadi 80,04 \% meningkat dibandingkan pada siklus II. Terlihat bahwa kegiatan pembelajaran dengan menerapkan model PBL dapat meningkatkan aktifitas mahasiswa, sehingga diharapkan juga dapat meningkatkan hasil belajar mahasiswa.

b. Analisis Data Keterampilan Berpikir Tingkat Tinggi (HOTS) Mahasiswa

Adapun data hasil asesmen HOTS mahasiswa selama penelitian (3 siklus) adalah sebagai berikut;

TABEL 4.7 Data HOTS mahasiswa

\begin{tabular}{cccccccccc}
\hline \multirow{2}{*}{ No.Subjek } & \multicolumn{3}{c}{ Gerak Lurus } & \multicolumn{3}{c}{ Hukum Newton } & \multicolumn{3}{c}{ Usaha dan Energi } \\
\cline { 2 - 11 } & pretes & postes & gain & pretes & postes & gain & pretes & postes & gain \\
\hline S1 & 60 & 80 & 0,50 & 75 & 80 & 0,20 & 85 & 90 & 0,50 \\
\hline S2 & 50 & 60 & 0,20 & 60 & 70 & 0,25 & 75 & 80 & 0,25 \\
\hline S3 & 65 & 75 & 0,29 & 75 & 80 & 0,20 & 80 & 85 & 0,33 \\
\hline S4 & 60 & 70 & 0,25 & 80 & 60 & $-1,00$ & 80 & 85 & 0,33 \\
\hline S5 & 50 & 60 & 0,20 & 65 & 60 & $-0,14$ & 80 & 85 & 0,33 \\
\hline S6 & 60 & 70 & 0,25 & 75 & 65 & $-0,40$ & 80 & 85 & 0,33 \\
\hline S7 & 60 & 80 & 0,50 & 50 & 60 & 0,20 & 80 & 85 & 0,33 \\
\hline S8 & 55 & 65 & 0,22 & 55 & 65 & 0,22 & 85 & 90 & 0,50 \\
\hline S9 & 65 & 60 & $-0,14$ & 55 & 75 & 0,44 & 80 & 85 & 0,33 \\
\hline
\end{tabular}




\begin{tabular}{cccccccccc}
\hline S10 & 65 & 65 & 0,00 & 75 & 85 & 0,40 & 75 & 80 & 0,25 \\
\hline S11 & 60 & 60 & 0,00 & 80 & 85 & 0,25 & 60 & 70 & 0,33 \\
\hline S12 & 70 & 60 & $-0,33$ & 85 & 90 & 0,33 & 80 & 80 & 0,00 \\
\hline S13 & 80 & 85 & 0,25 & 80 & 90 & 0,50 & 80 & 80 & 0,00 \\
\hline S14 & 65 & 60 & $-0,14$ & 75 & 70 & $-0,20$ & 60 & 75 & 0,60 \\
\hline S15 & 50 & 50 & 0,00 & 80 & 75 & $-0,25$ & 75 & 75 & 0,00 \\
\hline S16 & 60 & 60 & 0,00 & 80 & 75 & $-0,25$ & 85 & 90 & 0,50 \\
\hline S17 & 40 & 60 & 0,33 & 55 & 65 & 0,22 & 75 & 85 & 0,67 \\
\hline S18 & 60 & 60 & 0,00 & 75 & 85 & 0,40 & 75 & 90 & 1,50 \\
\hline S19 & 75 & 75 & 0,00 & 55 & 80 & 0,56 & 70 & 75 & 0,20 \\
\hline S20 & 60 & 75 & 0,38 & 75 & 80 & 0,20 & 80 & 85 & 0,33 \\
\hline S21 & 45 & 65 & 0,36 & 80 & 75 & $-0,25$ & 75 & 85 & 0,67 \\
\hline S22 & 60 & 55 & $-0,13$ & 55 & 75 & 0,44 & 80 & 90 & 1,00 \\
\hline S23 & 70 & 65 & $-0,17$ & 75 & 80 & 0,20 & 80 & 90 & 1,00 \\
\hline S24 & 70 & 60 & $-0,33$ & 75 & 80 & 0,20 & 70 & 80 & 0,50 \\
\hline S25 & 65 & 50 & $-0,43$ & 55 & 60 & 0,11 & 75 & 80 & 0,25 \\
\hline S26 & 40 & 65 & 0,42 & 75 & 85 & 0,40 & 60 & 65 & 0,14 \\
\hline Jumlah & 1560 & 1690 & 2,47 & 1820 & 1950 & 3,24 & 1980 & 2145 & 11,19 \\
\hline Rata-rata & 60,00 & 65,00 & 0,10 & 70,00 & 75,00 & 0,12 & 76,15 & 82,50 & 0,43 \\
\hline SD & 9,80 & 8,94 & & 10,86 & 9,49 & & 7,11 & 6,52 & \\
\hline
\end{tabular}

Dari TABEL 4.7 di atas terlihat pada siklus I, HOTS mahasiswa, rata-rata pretes adalah sebesar 60,00 dengan standar deviasi sebesar 9,80, setelah mendapatkan perlakuan pembelajaran model PBL berbasis HOTS postes rata-rata menjadi 65,00 standar deviasi sebesar 8,94. Dengan kata lain, HOTS mahasiswa mengalami peningkatan gain sebesar 0,10. Untuk membuktikan bahwa perbedaan kemampuan HOTS mahasiswa tiap siklus, maka dilakukan uji gain. Uji Normalitas Gain/n-gain menurut Hake adalah sebuah uji yang bisa memberikan GAMBARan umum peningkatan skor hasil pembelajaran antara sebelum dan sesudah diterapkannya metode tersebut (Hake, 1999 dalam Sundayana, 2016). Pada siklus II, Rata-rata HOTS pretes mahasiswa adalah sebesar 70,00 standar deviasi sebesar 10,86, setelah mendapatkan perlakuan pembelajaran model PBL rata-rata HOTS postes menjadi 75,00 standar deviasi sebesar 9,49. Dengan kata lain, HOTS mahasiswa mengalami peningkatan gain sebesar 0,12. Pada siklus III HOTS pretes mahasiswa rata-rata sebesar 76,15 standar deviasi sebesar 7,11, dan setelah mendapatkan perlakuan pembelajaran model PBL maka rata-rata HOTS postes menjadi 82,50 standar deviasi sebesar 6,52. Dengan kata lain, HOTS mahasiswa mengalami peningkatan gain sebesar 0,43. Dari hasil tersebut dapat kita bandingkan bahwa peningkatan HOTS siklus III lebih besar dibandingkan dengan peningkatan HOTS siklus II dan siklus I.

TABEL 4.8 Data Capaian HOTS Mahasiswa

\begin{tabular}{rrrrrrr}
\hline \multirow{2}{*}{ Nilai } & \multicolumn{2}{c}{ Siklus I } & \multicolumn{2}{c}{ Siklus II } & \multicolumn{2}{c}{ Siklus III } \\
\cline { 2 - 7 } & pretes & postes & pretes & postes & Pretes & postes \\
\hline$>70$ & $5(19,23)$ & $8(30,77)$ & $17(65,38)$ & $19(73,08)$ & $23(88,46)$ & $25(96,15)$ \\
\hline$<70$ & $21(80,77)$ & $18(69,23)$ & $9(34,62)$ & $7(26,92)$ & $3(11,54)$ & $1(3,85)$ \\
\hline Jumlah & 26 & 26 & 26 & 26 & 26 & 26 \\
\hline
\end{tabular}

Hasil tes keterampilan berpikir tingkat tinggi (HOTS) melalui pre test dan post test pada siklus I ditinjau dari persentase mahasiswa yang mencapai nilai > 70 adalah sebesar $19,23 \%$ meningkat menjadi 30,77\%, pada siklus II meningkat dari 65,38\% menjadi $73,08 \%$, dan pada siklus 
III dari $88,46 \%$ meningkat menjadi $96,15 \%$ dan persentase mahasiswa yang mencapai nilai $<70$ adalah sebesar $80,77 \%$ menurun menjadi $69,23 \%$, pada siklus II dari $34,62 \%$ menjadi $26,92 \%$, dan pada siklus III dari $11,54 \%$ menjadi $3,85 \%$.

Untuk membuktikan bahwa perbedaan pretes dan postes signifikan, maka dilakukan uji beda untuk nilai gainnya, GAMBAR 4.3. Hasil tersebut menunjukkan bahwa pembelajaran dengan problem based learning menghasilkan pencapaian yang lebih baik yaitu ada peningkatan HOTS mahasiswa.

TABEL 4.9 Statistik HOTS Mahasiswa

\begin{tabular}{lllllll}
\hline \multirow{2}{*}{ Uji Statistik } & \multicolumn{2}{l}{ Siklus I } & \multicolumn{5}{c}{ Siklus II } & \multicolumn{3}{c}{ Siklus III } \\
\cline { 2 - 7 } & Pretest & Postest & Pretest & Postest & Pretest & Postest \\
\hline Skor maksimum & 80 & 85 & 85 & 90 & 85 & 90 \\
\hline Skor minimum & 40 & 55 & 50 & 60 & 60 & 65 \\
\hline Gain & & 0,10 & & 0,12 & & 0,43 \\
\hline Mean & 60,00 & 65,00 & 70,00 & 75,00 & 76,15 & 82,50 \\
\hline Standar Deviasi & 9,80 & 8,94 & 10,86 & 9,49 & 7,11 & 6,52 \\
\hline
\end{tabular}

Berikut adalah GAMBARan kenaikan rata-rata HOTS mahasiswa pada setiap siklus yang ditunjukkan pada grafik dibawah ini.

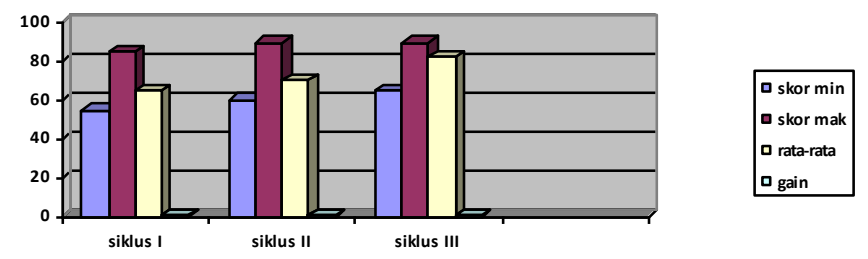

GAMBAR 3. Grafik Kenaikan HOTS Mahasiswa pada setiap siklus

Untuk membuktikan bahwa perbedaan kemampuan HOTS mahasiswa tiap siklus, maka dilakukan uji gain. Gain adalah selisih antara nilai postest dan pretest, gain menunjukkan peningkatan pemahaman atau penguasaan konsep mahasiswa setelah pembelajaran dilakukan dosen. Hasilnya adalah siklus I diperoleh gain sebesar 0,10, siklus II sebesar 0,12 dan siklus III sebesar 0,43.

c. Data Hasil Penilaian Karakter Mahasiswa

Selain bertujuan meningkatkan HOTS, PBL diorientasikan meningkatkan karakter mahasiswa juga. Dengan memperhatikan langkah-langkah PBL, karakter yang dilatihkan adalah jujur, disiplin, ingin tahu, dan tanggung jawab. Peningkatan karakter ini ditandai dengan semakin tingginya frekuensi penilaian diri mahasiswa pada penilaian kategori baik dan sangat baik. Data asesmen karakter mahasiswa pada penelitian ini disajikan dalam TABEL 4.10 berikut.

TABEL 4.10 Data Hasil Penilaian Karakter Mahasiswa

\begin{tabular}{|c|c|c|c|c|c|c|c|c|c|c|c|c|}
\hline \multirow{2}{*}{ No } & \multicolumn{2}{|c|}{ Jujur } & \multirow{2}{*}{ gain } & \multicolumn{2}{|c|}{ Disiplin } & \multirow{2}{*}{ gain } & \multicolumn{2}{|c|}{ Ingin Tahu } & \multirow{2}{*}{ Gain } & \multicolumn{2}{|c|}{ TanggJawab } & \multirow{2}{*}{ gain } \\
\hline & awal & akhir & & awal & akhir & & awal & akhir & & awal & akhir & \\
\hline 1 & 15 & 18 & 0,60 & 15 & 15 & 0,00 & 15 & 15 & 0,00 & 15 & 16 & 0,25 \\
\hline 2 & 15 & 17 & 0,40 & 15 & 15 & 0,00 & 14 & 15 & 0,17 & 15 & 15 & 0,00 \\
\hline 3 & 15 & 18 & 0,60 & 15 & 17 & 0,67 & 14 & 15 & 0,17 & 15 & 18 & 1,50 \\
\hline 4 & 15 & 16 & 0,20 & 14 & 15 & 0,20 & 15 & 15 & 0,00 & 15 & 15 & 0,00 \\
\hline 5 & 15 & 17 & 0,40 & 14 & 15 & 0,20 & 15 & 15 & 0,00 & 15 & 18 & 1,50 \\
\hline 6 & 17 & 18 & 0,33 & 15 & 17 & 0,67 & 14 & 15 & 0,17 & 15 & 15 & 0,00 \\
\hline 7 & 15 & 17 & 0,40 & 15 & 17 & 0,67 & 14 & 15 & 0,17 & 16 & 16 & 0,00 \\
\hline
\end{tabular}




\begin{tabular}{|c|c|c|c|c|c|c|c|c|c|c|c|c|}
8 & 17 & 18 & 0,33 & 15 & 15 & 0,00 & 14 & 15 & 0,17 & 15 & 15 & 0,00 \\
\hline 9 & 15 & 15 & 0,00 & 15 & 15 & 0,00 & 14 & 15 & 0,17 & 15 & 15 & 0,00 \\
\hline 10 & 17 & 19 & 0,67 & 15 & 15 & 0,00 & 15 & 15 & 0,00 & 15 & 15 & 0,00 \\
\hline 11 & 18 & 18 & 0,00 & 15 & 15 & 0,00 & 15 & 15 & 0,00 & 16 & 16 & 0,00 \\
\hline 12 & 18 & 18 & 0,00 & 15 & 15 & 0,00 & 14 & 15 & 0,17 & 15 & 15 & 0,00 \\
\hline 13 & 17 & 18 & 0,33 & 15 & 15 & 0,00 & 14 & 15 & 0,17 & 16 & 16 & 0,00 \\
\hline 14 & 15 & 17 & 0,40 & 15 & 15 & 0,00 & 14 & 15 & 0,17 & 15 & 15 & 0,00 \\
\hline 15 & 17 & 18 & 0,33 & 15 & 16 & 0,25 & 15 & 15 & 0,00 & 16 & 18 & 1,00 \\
\hline 16 & 16 & 17 & 0,25 & 16 & 16 & 0,00 & 14 & 15 & 0,17 & 15 & 15 & 0,00 \\
\hline 17 & 15 & 16 & 0,20 & 15 & 15 & 0,00 & 14 & 15 & 0,17 & 16 & 16 & 0,00 \\
\hline 18 & 17 & 17 & 0,00 & 15 & 15 & 0,00 & 14 & 15 & 0,17 & 15 & 15 & 0,00 \\
\hline 19 & 17 & 17 & 0,00 & 15 & 15 & 0,00 & 14 & 15 & 0,17 & 15 & 15 & 0,00 \\
\hline 20 & 18 & 18 & 0,00 & 15 & 15 & 0,00 & 15 & 15 & 0,00 & 15 & 16 & 0,25 \\
\hline 21 & 16 & 16 & 0,00 & 15 & 16 & 0,25 & 15 & 15 & 0,00 & 15 & 16 & 0,25 \\
\hline 22 & 18 & 18 & 0,00 & 15 & 15 & 0,00 & 15 & 15 & 0,00 & 15 & 15 & 0,00 \\
\hline 23 & 15 & 15 & 0,00 & 14 & 15 & 0,20 & 15 & 15 & 0,00 & 15 & 16 & 0,25 \\
\hline 24 & 17 & 18 & 0,33 & 15 & 15 & 0,00 & 15 & 15 & 0,00 & 15 & 16 & 0,25 \\
\hline 25 & 18 & 18 & 0,00 & 15 & 15 & 0,00 & 15 & 15 & 0,00 & 15 & 15 & 0,00 \\
\hline 26 & 17 & 18 & 0,33 & 15 & 16 & 0,25 & 15 & 15 & 0,00 & 15 & 15 & 0,00 \\
\hline $\mathrm{J} 1$ & 425 & 450 & 6,12 & 388 & 400 & 3,35 & 377 & 390 & 2,17 & 395 & 408 & 5,25 \\
\hline $\mathrm{X}$ & 16,35 & 17,31 & 0,24 & 14,92 & 15,38 & 0,13 & 14,50 & 15,00 & 0,08 & 15,19 & 15,69 & 0,20 \\
\hline $\mathrm{SD}$ & 1,20 & 1,01 & & 0,39 & 0,70 & & 0,51 & 0,00 & & 0,40 & 0,97 & \\
\hline
\end{tabular}

Dari TABEL 4.10 di atas nampak data karakter awal (sebelum pembelajaran) mahasiswa dan karakter akhir (setelah pembelajaran) setiap mahasiswa dan secara keseluruhan seperti (a) Jujur rata-rata adalah sebesar 16,35 dan setelah mendapatkan perlakuan pembelajaran model PBL berbasis HOTS dan pendidikan karakter rata-rata menjadi 17,31. Dengan kata lain karakter jujur mahasiswa mengalami peningkatan gain sebesar 0,24. (b) Disiplin rata-rata adalah sebesar 14,92 dan setelah mendapatkan perlakuan pembelajaran model PBL PBL berbasis HOTS dan pendidikan karakter rata-rata menjadi 15,38. Dengan kata lain karakter disiplin mahasiswa mengalami peningkatan gain sebesar 0,13. (c) Rasa Ingin tahu rata-rata keseluruhan adalah sebesar 14,50 dan setelah mendapatkan perlakuan pembelajaran model PBL berbasis HOTS dan pendidikan karakter rata-rata menjadi 15,00 . Dengan kata lain, karakter ingin tahu mahasiswa mengalami peningkatan gain sebesar 0,08. (d) tanggung jawab rata-rata adalah sebesar 15,19 dan setelah mendapatkan perlakuan pembelajaran model PBL berbasis HOTS dan pendidikan karakter menjadi rata-rata 15,69. Dengan kata lain, karakter tanggung jawab mahasiswa mengalami peningkatan gain sebesar 0,20 .

TABEL 4.11 Karakter Mahasiswa

\begin{tabular}{rlrrr}
\hline No & Jenis karakter & Asesmen Akhir & Asesmen Akhir & Gain \\
\hline 1 & Jujur & 16,35 & 17,31 & 0,24 \\
\hline 2 & Disiplin & 14,92 & 15,38 & 0,13 \\
\hline 3 & Ingin tahu & 14,50 & 15,00 & 0,08 \\
\hline 4 & Tanggung jawab & 15,19 & 15,69 & 0,20 \\
\hline & Jumlah & 60,96 & 63,38 & 0,65 \\
\hline & Rata-rata & 15,24 & 15,85 & 0,16 \\
\hline
\end{tabular}

Dari TABEL $4.11 \mathrm{di}$ atas nampak rata-rata karakter (jujur, disiplin, ingin tahu, tanggung jawab) awal mahasiswa atau sebelum pembelajaran adalah sebesar 15,24, setelah mendapatkan perlakuan pembelajaran menggunakan model PBL berbasis HOTS rata-rata karakternya menjadi 
15,85. Dengan kata lain, karakter mahasiswa mengalami peningkatan gain rata-rata sebesar 0,16. Dari hasil tersebut dapat kita bandingkan bahwa peningkatan karakter mahasiswa pada akhir pembelajaran (setelah perlakuan) lebih besar dibandingkan dengan awal (sebelum dikenai perlakuan).

Berikut grafik GAMBARan kenaikan karakter mahasiswa yang diukur sebelum pembelajaran dan setelah perlakuan dengan penerapan model pembelajaran berorientasi HOTS dan Karakter memalui Model PBL.

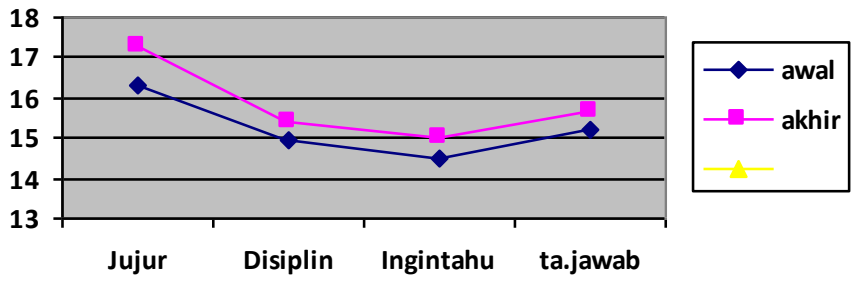

Fisika yang merupakan salah satu materi yang sangat terkait dengan kehidupan manusia, dapat berintegrasi dengan pendidikan karakter dalam kehidupan sehari-hari, mengingat fisika selalu ada di sekitar kita dan kaya akan pesan moral yang dapat membantu dalam pembentukan karakter mahasiswa. Pada proses pembelajaran, upaya membangun pengetahuan mahasiswa tentang konsepkonsep fisika, akan lebih bermakna jika mahasiswa mengalami sendiri apa yang sedang dipelajarinya, bukan hanya mengetahuinya secara teoritis-verbalistis. Bukti menunjukkan bahwa pembelajaran yang hanya berorientasi target materi, ternyata hanya berhasil dalam pemahaman untuk kompetisi jangka pendek, tetapi gagal dalam membekali anak didik untuk memecahkan masalah dan tersimpan dalam memori jangka panjang. Oleh sebab itu, agar konsep-konsep fisika dapat lebih mudah dipahami dan dikuasai dengan baik oleh mahasiswa dibutuhkan kemauan dan keuletan mahasiswa dalam belajar agar lebih bermakna, tidak hanya sekedar menghafal secara verbal. Dengan demikian, dalam upaya mencapai pengetahuan fisika yang mendalam, mahasiswa perlu dilatih dalam mengoptimalkan kemampuan berpikir tingkat tingginya termasuk melatih agar memiliki daya kreativitas yang tinggi.

\section{SIMPULAN}

Berdasarkan hasil penelitian dan pembahasan diperoleh simpulan sebagai berikut:

1. Ada peningkatan aktivitas belajar mahasiswa dengan penerapan model Perangkat Pembelajaran Fisika Berorientasi HOTS dan Pendidikan Karakter melalui Pembelajaran Berbasis Masalah (Problem Based Learning) pada mata kuliah fisika dasar di Program Studi Pendidikan IPA FKIP Universitas Bengkulu.

Pada siklus I sebanyak 65,48 \% mahasiswa dapat dikatakan melakukan aktifitas pembelajaran dengan baik, kemudian pada siklus II meningkat menjadi 76,40 \% siswa, dan pada siklus III menjadi 80,04\%.

2. Ada peningkatan Keterampilan Berpikir Tingkat Tinggi (HOTS) mahasiswa dengan penerapan Model Perangkat Pembelajaran Fisika Berorientasi HOTS dan Pendidikan Karakter melalui Pembelajaran Berbasis Masalah (Problem Based Learning) pada mata kuliah fisika dasar di Program Studi Pendidikan IPA FKIP Universitas Bengkulu, yakni siklus I, HOTS mahasiswa, rata-rata pretes adalah sebesar 60,00 dengan standar deviasi sebesar 9,80, setelah mendapatkan perlakuan pembelajaran model PBL berbasis HOTS postes rata-rata menjadi 65,00 standar deviasi sebesar 8,94. Dengan kata lain, HOTS mahasiswa mengalami peningkatan gain sebesar 0,10. Pada siklus II, Rata-rata HOTS pretes mahasiswa adalah sebesar 70,00 standar deviasi sebesar 10,86, setelah mendapatkan perlakuan pembelajaran 
model PBL rata-rata HOTS postes menjadi 75,00 standar deviasi sebesar 9,49. Dengan kata lain, HOTS mahasiswa mengalami peningkatan gain sebesar 0,12. Pada siklus III HOTS pretes mahasiswa rata-rata sebesar 76,15 standar deviasi sebesar 7,11 , dan setelah mendapatkan perlakuan pembelajaran model PBL maka rata-rata HOTS postes menjadi 82,50 standar deviasi sebesar 6,52. Dengan kata lain, HOTS mahasiswa mengalami peningkatan gain sebesar 0,43. Dari hasil tersebut dapat kita bandingkan bahwa peningkatan HOTS siklus III lebih besar dibandingkan dengan peningkatan HOTS siklus II dan siklus I.

3. Ada peningkatan karakter mahasiswa dengan penerapan Model Perangkat Pembelajaran Fisika Berorientasi HOTS dan Pendidikan Karakter melalui Pembelajaran Berbasis Masalah (Problem Based Learning) pada mata kuliah fisika dasar di Program Studi Pendidikan IPA FKIP Universitas Bengkulu. Karakter awal (sebelum pembelajaran) mahasiswa dan karakter akhir (setelah pembelajaran) setiap mahasiswa dan secara keseluruhan adaalah (a) Jujur rata-rata adalah sebesar 16,35 dan setelah mendapatkan perlakuan pembelajaran model PBL berbasis HOTS dan pendidikan karakter rata-rata menjadi 17,31. Dengan kata lain karakter jujur mahasiswa mengalami peningkatan gain sebesar 0,24. (b) Disiplin rata-rata adalah sebesar 14,92 dan setelah mendapatkan perlakuan pembelajaran model PBL PBL berbasis HOTS dan pendidikan karakter rata-rata menjadi 15,38. Dengan kata lain karakter disiplin mahasiswa mengalami peningkatan gain sebesar 0,13. (c) Rasa Ingin tahu rata-rata keseluruhan adalah sebesar 14,50 dan setelah mendapatkan perlakuan pembelajaran model PBL berbasis HOTS dan pendidikan karakter rata-rata menjadi 15,00. Dengan kata lain, karakter ingin tahu mahasiswa mengalami peningkatan gain sebesar 0,08. (d) tanggung jawab rata-rata adalah sebesar 15,19 dan setelah mendapatkan perlakuan pembelajaran model PBL berbasis HOTS dan pendidikan karakter menjadi rata-rata 15,69. Dengan kata lain, karakter tanggung jawab mahasiswa mengalami peningkatan gain sebesar 0,20 .

\section{REFERENSI}

[1] Kemendikbud.2014. Buku Guru Ilmu pengetahuan Alam SMP/MTSN Kelas VIII. Jakarta: Kementerian Pendidikan dan Kebudayaan

[2] Widodo, T \& Kadarwati, S. 2013. High Order Thinking Berbasis Pemecahan Masalah Untuk Meningkatkan Hasil Belajar Berorientasi Pembentukan Karakter Siswa. Cakrawala Pendidikan 32(1),

[3] Andriani, D. (2016); Efektivitas Problem Based Learning (PBL) Berbantuan LKS Tema Gerak Terhadap High Order Thinking Skill Siswa SMP . Skripsi. Jurusan IPA Terpadu Fakultas Matematika dan Ilmu Pengetahuan Alam Universitas Negeri Semarang.

[4] Anderson, L., et al (2001), A Taxonomy for Learning,Teaching, and Assessing: A revision of Bloom's Taxonomy of Educational Objectives, New York: Pearson, Allyn \& Bacon.

[5] Sudjana, Nana. Dasar-dasar Proses Belajar Mengajar (Bandung: Sinar Baru Algensindo, 2009)

[6] Syaifulloh Bakhri dan Supriadi (2017). Peran Problem-Based Learning (PBL) dalam Upaya Peningkatan Higher Order Thinking Skills (HOTS) Siswa pada Pembelajaran Matematika. ISBN. 978-602-73403-2-9 (Cetak) 